\title{
KAJIAN TINJAUAN HUBUNGAN ETNIK DALAM KALANGAN PELAJAR TAHUN SATU DI KAMPUS JOHOR BAHRU, UNIVERSITI TEKNOLOGI MALAYSIA (UTM)
}

\author{
HAMIDAH AB RAHMAN ${ }^{1}$, HAMIDAH ABD RAHMAN ${ }^{2}$, \\ NORLIN AHMAD ${ }^{3}$, NOR AKMAR NORDIN ${ }^{4}$, NORASHIKIN \\ MAHMUD $^{5}$, ROZIANAN SHAARI ${ }^{6} \&$ SHAH ROLLAH \\ ABDUL WAHAB ${ }^{7}$
}

\begin{abstract}
Abstrak. Kajian ini membincangkan tentang tahap hubungan sosial dan patriotisme dalam kalangan pelajar tahun satu Kampus Johor Bahru, UTM. Seramai 521 pelajar yang telah mengikuti kursus Hubungan Etnik (KHE) menjadi responden kajian ini. Kajian ini merupakan kajian tinjauan yang menggunakan borang soal selidik. Skop kajian ini tentang hubungan sosial daripada perspektif perpaduan kaum dan partriotisme yang melibatkan kecintaan, kebanggaan dan kesetiaan kepada negara. Data dianalisis menggunakan kekerapan, peratusan dan min. Hasil kajian menunjukkan tahap hubungan sosial pelajar tahun satu adalah berada pada tahap sederhana. Manakala patriotisme pula berada pada tahap tinggi. Beberapa cadangan juga dikemukakan untuk memperbaiki kelemahan-kelemahan kepada pengajaran dan pembelajaran kursus Hubungan Etnik di UTM.
\end{abstract}

Kata kunci: Hubungan etnik; perpaduan; hubungan sosial; patriotisme; masyarakat majmuk; polarisasi

\begin{abstract}
This research discusses the level of social relation and patriotism among first year students in Johor Bahru Campus, UTM. Respondents of this study were 521 students enrolled in the Ethnic Relation course. A survey method using questionnaire was used. The scopes of the study include social relation from the perspective of ethnic unity and patriotism in the context of love, admiration and loyalty to the country. Data were analyzed using frequency, percentage and mean. The findings showed that the level of social relation among the first year students was at a moderate level, whereas the level of patriotism was high. Several recommendations are given to improve the weaknesses of teaching and learning in Ethnic Relation course at UTM.
\end{abstract}

Keywords: Ethnic relation; unity; social relation; patriotism; plural society; polarization

Jabatan Pembangunan Sumber Manusia, Fakulti Pengurusan dan Pembangunan Sumber Manusia, UTM Johor Bahru, 81310 Johor Darul Ta'azim 


\subsection{LATAR BELAKANG KAJIAN}

Malaysia terdiri daripada masyarakat majmuk yang unik dan terkenal sebagai sebuah masyarakat yang telah berjaya serta menjadi model masyarakat majmuk yang hidup aman damai kepada negara-negara luar. Keunikan ini wujud kerana walaupun penduduknya terdiri daripada berbilang etnik, namun konflik antara etnik jarang berlaku. Bagi Malaysia, kepelbagaian etnik merupakan suatu kekuatan yang mewarnai corak negara ini. Rakyat Malaysia yang pelbagai etnik ini mampu menyelesaikan masalah dan mengelakkan konflik dengan cara tersendiri. Kesemua ini menggambarkan bahawa wujudnya perpaduan kaum. Konsep perpaduan di Malaysia bermaksud satu proses menyatupadukan anggota-anggota masyarakat dan negara seluruhnya melalui ideologi negara supaya tiap-tiap anggota masyarakat dapat membentuk satu identiti dan nilai bersama di kalangan mereka (Institut Tadbiran Awan Negara Malaysia, 1997).

Sebenarnya perpaduan yang wujud di Malaysia hari ini bukanlah terbentuk dengan sendirinya. Pelbagai usaha dilaksanakan oleh kerajaan termasuklah penggunaan kaedah pembangunan sosio-ekonomi dan pembangunan sosiopsikologi. Kaedah pembangunan sosio-psikologi misalnya melibatkan media massa, pelancongan dalam negeri, aktiviti-aktiviti sosial, kelompok-kelompok sosial, pendidikan lanjutan, aktiviti-aktiviti ko-kurikulum dan pendidikan formal. Bagi pendidikan formal misalnya, ia merupakan proses pemasyarakatan di peringkat sekolah serta pengajian tinggi, kurikulumnya yang telah diisi dengan unsur-unsur yang dapat memberi pengetahuan yang mendalam tentang kumpulan-kumpulan etnik negeri ini dengan pemupukkan semangat bersatu padu. Bagi aktiviti-aktiviti ko-kurikulum pula, semua institusi pengajian telah digalakkan mengadakan aktiviti-aktiviti ko-kurikulum yang melibatkan semua pelajar untuk memberi manfaat serta merapatkan hubungan sosial di kalangan semua kumpulan etnik.

Di Malaysia, masalah perpaduan sering dihubungkaitkan dengan polarisasi. Polarisasi bermaksud pembahagian golongan tertentu mempunyai amalan atau pendirian yang berbeza sehingga mewujudkan beberapa kelompok anggota masyarakat yang bertentangan dengan kelompok yang lain. Polarisasi wujud kerana perbezaan latar belakang, agama dan nilai hidup. Polarisasi menjadi lebih ketara apabila kelompok yang mempunyai perbezaan nilai memiliki keinginan serta hasrat yang berlainan sehingga menimbulkan konflik dalam pelbagai bentuk. Masalah polarisasi perlu ditangani dan perpaduan merupakan strategi terbaik (Nazarudin et al., 2001). Kerajaan telah mengambil beberapa pendekatan bagi mengatasi masalah polarisasi kaum melalui Jabatan Perpaduan Negara. Antara aktiviti yang telah dilaksanakan ialah konsep kejiranan, Rukun Tetangga dan Kelas Tabika Perpaduan yang dijangka dapat memupuk perpaduan melalui aktiviti kerjasama antara kaum. Di samping itu, kerajaan juga telah mengambil 
pendekatan melalui kerjasama kakitangan kerajaan bagi mengesan iklim hubungan sosial di kalangan rakyat. Agen penyemai perpaduan yang penting ialah institusi pendidikan termasuk sekolah dan institusi pengajian tinggi.

Jika dilihat daripada kaedah-kaedah menyatupadukan etnik dan menghapuskan polarisasi kaum, jelas bahawa peranan hubungan sosial adalah penting. Istilah 'hubungan sosial' adalah istilah yang digunakan untuk merujuk kepada hubungan atau interaksi antara manusia (Diana, terjemahan Noor Sharifah, 1990). Melalui interaksi inilah anggota masyarakat yang terdiri daripada pelbagai etnik dapat bersama-sama memahami budaya dalam kalangan etniketnik yang berbeza yang sehingga kini rakyat Malaysia masih mengaku bahawa perpaduan sememangnya wujud dan akan berterusan. Namun begitu, pada pertengahan tahun 2005, Institut Pengajian Tinggi (IPT) telah dikejutkan dengan satu edaran daripada Jabatan Pengurusan Pengajian Tinggi yang berupa arahan memantapkan kurikulum kursus Tamadun Islam dan Tamadun Asia (TITAS) dan pelaksanaan Kursus Hubungan Etnik (KHE) di Institusi Pengajian Tinggi Awam (IPTA). Arahan tersebut dibuat berdasarkan satu kajian yang telah dijalankan oleh Institut Penyelidikan Pendidikan Tinggi Negara (IPPTN) terhadap 6,000 orang pelajar di IPTA, mendapati bahawa polarisasi kaum masih wujud dalam kalangan pelajar-pelajar IPTA. Hasil daripada kajian tersebut Kementerian telah bersetuju dengan cadangan perubahan Kurikulum Kursus Tamadun Islam, Tamadun Asia (TITAS) dan Kursus Hubungan Etnik (KHE).

(i) Kurikulum kursus TITAS yang asalnya empat jam kredit perlu dirombak dan dimantapkan menjadi dua jam kredit.

(ii) Kursus Hubungan Etnik dijadikan dua jam kredit.

(iii) Kursus TITAS dan Hubungan Etnik adalah Kursus Wajib universiti.

(iv) Kedua-dua kursus ini mula dilaksanakan dengan pengambilan pelajar sesi 2005/2006.

(v) Semua IPTA perlu menggunakan kurikulum yang seragam.

Adalah diharapkan bahawa hasil pembelajaran KHE ini, antaranya ialah siswazah dapat mengenal pelbagai budaya dan etnik yang terdapat di Malaysia serta lebih meningkatkan rasa tanggungjawab antara satu etnik dengan satu etnik yang lain. Di samping itu, siswazah dapat memahami cabaran pluralisasi budaya dan permuafakatan sosial di Malaysia yang menjadi asas kepada keharmonian hubungan etnik dan kecintaan terhadap negara. Persoalannya, wajarkah masalah polarisasi di IPTA ini ditangani melalui kursus Hubungan Etnik di IPTA? Bukankah "melentur buluh perlu di waktu rebung”? Selama ini warga IPTA telah lama mengetahui tentang masalah ini dan cuba menanganinya dengan pelbagai cara, namun kurang berjaya. Sebagai contoh, pihak pentadbiran atasan UTM telah mengarah pensyarah yang terlibat dalam pengajaran kursus wajib untuk membuat 
beberapa kajian terhadap keberkesanan kursus wajib di UTM yang berkaitan dengan semangat perpaduan, jati diri, patriotisme dan lain-lain (Hamidah et al., 2001 dan Rosman et al., 2000).

Malah sebelum kursus hubungan etnik diperkenalkan pelajar IPTA telah pun diwajibkan mengambil kursus Kenegaraan Malaysia iaitu kursus tentang sistem sosial, ekonomi, politik, patriotik dan bangga terhadap negara, menghargai jasajasa pejuang yang lampau, bersikap terbuka, toleransi serta sedia memberi sumbangan dan pengorbanan demi rakyat dan negara kepada pelajar-pelajar tahun satu. Namun hubungan antara etnik di IPT masih juga dingin dan hampir beku. Justeru itu, berdasarkan apa yang telah berlaku, maka satu kajian telah dibuat oleh beberapa pensyarah yang terlibat dalam pengajaran kursus wajib ini untuk melihat sejauhmana interaksi sosial pelajar berbilang kaum di IPTA. Jika tahap perpaduan mereka rendah atau sederhana, maka masalah polarisasi ini sebenarnya perlu ditangani di peringkat sekolah rendah hingga menengah bukan setelah mereka melangkah ke IPTA. Maka, persoalan kajian adalah seperti berikut:

(i) Sejauhmanakah tahap hubungan sosial dalam kalangan pelajar tahun satu di Kampus Johor Bahru UTM.

(ii) Sejauhmanakah tahap patriotisme dalam kalangan pelajar tahun satu di Kampus Johor Bahru UTM.

\subsection{METODOLOGI}

Kajian ini merupakan kajian tinjauan terhadap pelajar tahun satu yang mengambil KHE di Kampus Johor Bahru UTM. Tujuan kajian adalah untuk mengetahui tahap hubungan sosial dan semangat patriotisme mereka. Sebanyak 600 soal selidik telah diedarkan dan 521 (86\%) soal selidik telah dikembalikan. Soal selidik terdiri daripada tiga bahagian: demografi, hubungan sosial dan patriotisme. Dalam kajian ini, hubungan etnik merujuk kepada interaksi sosial antara pelajar tahun satu yang terdiri daripada pelbagai etnik di Kampus Johor Bahru UTM. Manakala patriotisme merujuk kepada semangat kecintaan, kebanggaan dan kesetiaan kepada negara dalam kalangan pelajar tahun satu di Kampus Johor Bahru UTM. Aspek yang dikaji dalam hubungan sosial adalah daripada perspektif perpaduan kaum manakala patriotisme dilihat daripada sudut kecintaan, kebanggaan, dan kesetiaan kepada negara. Data dianalisis secara statistik deskriptif yang menggunakan kekerapan, peratusan dan min. 


\subsection{DAPATAN KAJIAN DAN PERBINGANGAN}

Jadual 1.1 menunjukkan taburan kekerapan dan peratusan demografi pelajar Tahun Satu yang sedang mengikuti KHE. Dari segi jantina responden, responden perempuan adalah $65.3 \%$ mengatasi peratusan responden lelaki iaitu 34.7\%. Manakala daripada segi etnik, peratusan responden Melayu paling tinggi iaitu sebanyak $68.9 \%$ diikuti responden Cina 27.3\%, India $1.5 \%$ dan lain-lain 2.3\%. Mengenai latar belakang responden, majoriti responden merupakan bekas pelajar Sekolah Menengah Kebangsaan (58.2\%) dan Sekolah Menengah Sains MARA (MRSM) (16.9\%). Ini diikuti Sekolah Teknik sebanyak 7.7\% dan Sekolah Berasrama Penuh 7.3\%. Majoriti responden adalah dari kawasan bandar iaitu sebanyak 53.9\% dan selebihnya $46.1 \%$ adalah dari luar bandar.

\subsection{OBJEKTIF}

\subsection{Objektif 1: Tahap Hubungan Sosial Dan Semangat Patriotisme Pelajar Tahun Satu Dari Perspektif Perpaduan Kaum}

Jadual 1.1 Taburan kekerapan dan peratusan demografi pelajar tahun satu

\begin{tabular}{c|c|c|c}
\hline Demografi & Profil & Kekerapan & Peratusan \\
\hline Jantina & Lelaki & 181 & 34.7 \\
& Perempuan & 340 & 65.3 \\
Etnik & Melayu & 359 & 68.9 \\
& Cina & 142 & 27.3 \\
India & 8 & 1.5 \\
Sekolah & Lain-lain & 12 & 2.3 \\
& & 38 & 7.3 \\
& Sekolah berasrama penuh & 88 & 16.9 \\
& Maktab Rendah Sains MARA & 303 & 58.2 \\
& Sekolah Menengah Kebangsaan & 28 & 5.4 \\
& Sekolah agama & 2 & 0.4 \\
& Sekolah swasta & 40 & 7.7 \\
Sekolah teknik & 22 & 4.2 \\
& Sekolah Rendah Jenis Kebangsaan & & 8 \\
& Perlis & 4 & 6.7 \\
& Kedah & 35 & 5.0 \\
& Pulau Pinang & 56 & 10.7 \\
& Perak & 68 & 13.1 \\
& Kelantan & 28 & 5.4 \\
\hline
\end{tabular}


Sambungan Jadual 1.1

\begin{tabular}{c|c|c|c}
\hline Demografi & Profil & Kekerapan & Peratusan \\
\hline Negeri Kelahiran & Pahang & 36 & 6.9 \\
& Johor & 99 & 19.0 \\
& Melaka & 12 & 2.3 \\
& Negeri Sembilan & 27 & 5.2 \\
& Kuala Lumpur & 27 & 5.2 \\
& Selangor & 48 & 9.2 \\
Kawasan Tempat & Sabah & 23 & 4.4 \\
Tinggal & Sarawak & 32 & 6.1 \\
& & 281 & 53.9 \\
\hline
\end{tabular}

Jadual 1.2 Taburan Kekerapan dan Peratusan Bagi Dimensi Hubungan Sosial Di Kalangan Pelajar Tahun Satu

\begin{tabular}{|c|c|c|c|c|c|c|c|c|}
\hline \multicolumn{2}{|l|}{ Item } & SS & $\mathbf{S}$ & KS & TS & STS & Min & Tahap \\
\hline $\begin{array}{l}\text { Keluar makan bersama } \\
\text { rakan berlainan etnik }\end{array}$ & $f(\%)$ & $\begin{array}{c}38 \\
(7.3)\end{array}$ & $\begin{array}{c}18 \\
(22.6)\end{array}$ & $\begin{array}{c}235 \\
(45.1)\end{array}$ & $\begin{array}{l}130 \\
(25)\end{array}$ & $0(0)$ & 2.12 & Sederhana \\
\hline $\begin{array}{l}\text { Selalu beriadah bersama } \\
\text { rakan berlainan etnik }\end{array}$ & $f(\%)$ & $\begin{array}{c}40 \\
(7.7) \\
\end{array}$ & $\begin{array}{c}141 \\
(27.1) \\
\end{array}$ & $\begin{array}{c}234 \\
(44.9) \\
\end{array}$ & $\begin{array}{c}106 \\
(20.3) \\
\end{array}$ & (0) $(0)$ & 2.22 & Sederhana \\
\hline $\begin{array}{l}\text { Keluar membeli belah } \\
\text { bersama rakan berlainan } \\
\text { etnik }\end{array}$ & $f(\%)$ & $\begin{array}{c}29 \\
(5.6)\end{array}$ & $\begin{array}{c}70 \\
(13.4)\end{array}$ & $\begin{array}{c}281 \\
(53.9)\end{array}$ & $\begin{array}{c}141 \\
(27.1)\end{array}$ & $0(0)$ & 1.98 & Rendah \\
\hline $\begin{array}{l}\text { Bersiar bersama rakan } \\
\text { berlainan etnik }\end{array}$ & $f(\%)$ & $\begin{array}{c}28 \\
(5.4)\end{array}$ & $\begin{array}{c}110 \\
(21.1)\end{array}$ & $\begin{array}{c}259 \\
(49.7)\end{array}$ & $\begin{array}{c}124 \\
(23.8)\end{array}$ & (0) $(0)$ & 2.08 & Sederhana \\
\hline $\begin{array}{l}\text { Saya sedia tinggal sebilik } \\
\text { dengan rakan berlainan etnik }\end{array}$ & $f(\%)$ & $\begin{array}{c}64 \\
(12.3)\end{array}$ & $\begin{array}{c}206 \\
(39.5)\end{array}$ & $\begin{array}{l}153 \\
(29.4)\end{array}$ & $\begin{array}{c}98 \\
(18.8)\end{array}$ & $0(0)$ & 2.45 & Sederhana \\
\hline $\begin{array}{l}\text { Saya lebih selesa berkawan } \\
\text { rapat dengan berlainan etnik }\end{array}$ & $f(\%)$ & $\begin{array}{c}35 \\
(6.7) \\
\end{array}$ & $\begin{array}{c}168 \\
(32.2)\end{array}$ & $\begin{array}{l}276 \\
(53) \\
\end{array}$ & $\begin{array}{c}42 \\
(8.1)\end{array}$ & (0) $(0)$ & 2.38 & Sederhana \\
\hline $\begin{array}{l}\text { Membantu rakan berlainan } \\
\text { etnik jika mereka } \\
\text { bermasalah }\end{array}$ & $f(\%)$ & $\begin{array}{c}96 \\
(18.4)\end{array}$ & $\begin{array}{c}299 \\
(57.4)\end{array}$ & $\begin{array}{c}106 \\
(20.3)\end{array}$ & $\begin{array}{c}20 \\
(3.8)\end{array}$ & $0(0)$ & 2.90 & Sederhana \\
\hline $\begin{array}{l}\text { Selesa membuat tugasan } \\
\text { akademik bersama rakan } \\
\text { berbilang etnik }\end{array}$ & $f(\%)$ & $\begin{array}{c}148 \\
(28.4)\end{array}$ & $\begin{array}{c}278 \\
(53.4)\end{array}$ & $\begin{array}{l}73 \\
(14)\end{array}$ & $\begin{array}{c}22 \\
(4.2)\end{array}$ & $0(0)$ & 3.06 & Tinggi \\
\hline
\end{tabular}


Sambungan Jadual 1.2

\begin{tabular}{|c|c|c|c|c|c|c|c|c|}
\hline $\begin{array}{l}\text { Meminjamkan wang kepada } \\
\text { rakan berlainan etnik }\end{array}$ & $f(\%)$ & $\begin{array}{c}67 \\
(12.9) \\
\end{array}$ & $\begin{array}{c}174 \\
(33.4) \\
\end{array}$ & $\begin{array}{c}140 \\
(26.9) \\
\end{array}$ & $\begin{array}{c}140 \\
(26.9) \\
\end{array}$ & (0) $(0)$ & 2.32 & Sederhana \\
\hline $\begin{array}{l}\text { Bergaul mesra denganjiran } \\
\text { dari etnik berbeza }\end{array}$ & $f(\%)$ & $\begin{array}{c}101 \\
(19.4)\end{array}$ & $\begin{array}{c}258 \\
(49.5)\end{array}$ & $\begin{array}{c}114 \\
(21.9)\end{array}$ & $\begin{array}{c}48 \\
(9.2)\end{array}$ & $0(0)$ & 2.79 & Sederhana \\
\hline $\begin{array}{l}\text { Mengunjungi etnik berbeza } \\
\text { pada hari perayaan mereka }\end{array}$ & $f(\%)$ & $\begin{array}{c}62 \\
(11.9)\end{array}$ & $\begin{array}{c}201 \\
(38.6)\end{array}$ & $\begin{array}{c}178 \\
(34.2)\end{array}$ & $\begin{array}{c}80 \\
(15.4)\end{array}$ & $0(0)$ & 2.47 & Sederhana \\
\hline $\begin{array}{l}\text { Menyertai persatuan } \\
\text { pelbagai etnik }\end{array}$ & $f(\%)$ & $\begin{array}{c}79 \\
(15.2) \\
\end{array}$ & $\begin{array}{c}262 \\
(50.3) \\
\end{array}$ & $\begin{array}{c}150 \\
(28.8) \\
\end{array}$ & $\begin{array}{c}30 \\
(5.8) \\
\end{array}$ & () $(0)$ & 2.75 & Sederhana \\
\hline $\begin{array}{l}\text { Bersedia membantu etnik } \\
\text { lain yang memerlukan } \\
\text { bantuan }\end{array}$ & $f(\%)$ & $\begin{array}{c}154 \\
(29.6)\end{array}$ & $\begin{array}{c}303 \\
(58.2)\end{array}$ & $\begin{array}{c}48 \\
(9.2)\end{array}$ & $\begin{array}{c}16 \\
(3.1)\end{array}$ & $0(0)$ & 3.14 & Tinggi \\
\hline $\begin{array}{l}\text { Hanya bersedia menerima } \\
\text { pemimpin pelajar etnik saya }\end{array}$ & $f(\%)$ & $\begin{array}{c}62 \\
(11.9)\end{array}$ & $\begin{array}{c}114 \\
(21.9)\end{array}$ & $\begin{array}{c}209 \\
(40.1)\end{array}$ & $\begin{array}{c}136 \\
(26.1)\end{array}$ & () $(0)$ & 2.20 & Sederhana \\
\hline $\begin{array}{l}\text { Hanya mengenali pemimpin } \\
\text { politik etnik saya }\end{array}$ & $f(\%)$ & $\begin{array}{c}60 \\
(11.5) \\
\end{array}$ & $\begin{array}{l}195 \\
(37.4) \\
\end{array}$ & $\begin{array}{c}186 \\
(35.7) \\
\end{array}$ & $\begin{array}{c}80 \\
(15.4) \\
\end{array}$ & $0(0)$ & 2.45 & Sederhana \\
\hline $\begin{array}{l}\text { Lebih mengikuti } \\
\text { perkembangan politik etnik } \\
\text { saya }\end{array}$ & $f(\%)$ & $\begin{array}{c}60 \\
(11.5)\end{array}$ & $\begin{array}{c}195 \\
(37.4)\end{array}$ & $\begin{array}{c}186 \\
(35.7)\end{array}$ & $\begin{array}{c}80 \\
(15.4)\end{array}$ & $0(0)$ & 2.57 & Sederhana \\
\hline Min keseluruhan & & \multicolumn{6}{|c|}{24.9} & Sederhana \\
\hline
\end{tabular}

Nota: $\mathrm{SS}=$ Sangat Setuju, $\mathrm{S}=$ Setuju,KS= Kurang Setuju, TS= Tidak Setuju, STS= Sangat Tidak Setuju, $f=$ Kekerapan, $\%=$ Peratusan

Jadual 1.2 menunjukkan tahap hubungan sosial pelajar tahun satu di UTM Skudai, Johor. Melalui dapatan kajian, didapati pelajar-pelajar yang melakukan aktiviti seperti keluar makan bersama, beriadah dan bersiar-siar dengan rakan berlainan etnik adalah pada tahap sederhana. Selain daripada itu pelajar yang bersedia untuk tinggal sebilik dan berkawan rapat dengan rakan berlainan agama juga berada pada tahap sederhana. Ini adalah disebabkan faktor pantang larang dan amalan sesetengah agama yang berbeza antara satu dengan yang lain tidak memungkinkan sesetengah mereka untuk bersedia berbuat demikian. Begitu juga, elemen seperti memberi bantuan, meminjamkan wang, bergaul mesra dengan jiran dan kaum berbeza dan mengunjungi mereka di hari perayaan juga berada pada tahap sederhana.

Walau bagaimanapun dari segi melaksanakan tugasan akademik bersama rakan berlainan etnik $(M=3.06)$ dan bersedia membantu rakan berbilang etnik jika mereka menghadapi masalah adalah pada tahap yang tinggi. Menurut Teori Pertukaran Sosial (Blau, 1964) yang menyatakan bahawa hubungan antara dua individu adalah untuk memenuhi keperluan bersama dan mengurangkan kerugian yang bakal dialami. Semasa pertukaran berlaku, setiap pihak memberi penilaian 
terhadap tingkah laku rakan lain dan membuat keputusan sama ada untuk meneruskan hubungan antara kedua belah pihak atau pun tidak. Memandangkan pelajar tidak keberatan untuk tinggal bersama dalam satu bilik, membuat tugasan bersama, maka mereka akan kerap berjumpa dan berinteraksi antara satu sarna lain. Semakin kerap berjumpa antara satu sama lain akan semakin banyak maklumat yang diperolehi untuk membuat penilaian sama ada untuk mempercayai antara satu sama lain atau sebaliknya (Holmes et al., 1985).

Kepercayaan terhadap etnik lain dapat meningkatkan tahap hubungan sosial antara pelajar dari berbilang etnik kerana ada sesetengah daripada mereka yang datang dari latar belakang yang tidak pernah bergaul dengan etnik lain dan mempunyai tanggapan yang negatif terhadap berlainan etnik. Apabila diberi peluang bergaul, mereka merasakan terdapat banyak persamaan, kebaikan dan keburukan yang perlu dikongsi bersama. Di samping itu, daripada pengalaman pengkaji, terdapat pelajar yang menyatakan bahawa dengan membuat kerja dalam kumpulan yang terdiri daripada berbilang etnik, memberi mereka peluang untuk mengenali antara satu sama lain dengan lebih dekat walaupun ia merupakan satu peraturan bagi sesetengah pensyarah yang mewajibkan kumpulan dibentuk daripada pelajar berbilang etnik. Mereka juga menyatakan bahawa membuat kerja bersama membantu mereka mengimbangkan perasaan prejudis, stereotaip dan etnosentrisme yang tidak berasas terhadap etnik lain.

Namun begitu, daripada hasil kajian ini juga didapati aktiviti keluar membeli belah dengan rakan berlainan etnik adalah pada tahap yang rendah, ini mungkin disebabkan pelajar lebih selesa melakukan aktiviti tersebut dengan rakan rapat daripada etnik yang sama kerana lebih memahami kehendak antara satu sama lain dan hanya lebih selesa melakukan aktiviti tersebut dengan rakan yang rapat. Mengikut Teori Similarity Attraction Paradigm (T'sui dan O'reilly, 1989), individu lebih tertarik dengan mereka yang mempunyai kesamaan dari segi latar belakang demografi. Oleh yang demikian, pelajar dari latar belakang etnik yang sama akan merasa lebih selesa untuk keluar membeli belah bersama kerana mungkin lebih memahami tentang kehendak bersama.

Manakala dari aspek politik, seperti hanya bersedia menerima pemimpin pelajar sebangsa, hanya mengenali pemimpin politik sebangsa dan lebih mengikuti perkembangan politik kaum sendiri adalah di tahap sederhana. Ini menunjukkan mereka mempunyai fikiran yang lebih terbuka dari aspek politik yang mana mereka menerima pemimpin tanpa berasaskan kaum. Ini mungkin disebabkan oleh kebolehan dan kemampuan pemimpin sebagai menjalankan tanggungjawab sebagai ketua. Hasil kajian menunjukkan tahap hubungan sosial pelajar Tahun Satu di UTM adalah berada pada tahap sederhana $(\mathbf{M}=2.49)$. Keputusan ini adalah satu yang membimbangkan kerana untuk mengukuhkan sebuah negara yang bersatu padu selaras dengan matlamat Wawasan 2020 untuk mewujudkan satu bangsa Malaysia, kita memerlukan hubungan sosial berada pada tahap tinggi. 
Ini menunjukkan sebuah masyarakat yang bersatupadu terutama di kalangan generasi muda di peringkat sekolah rendah dan menengah belum tercapai seperti apa yang diharapkan. Mungkin sesetengah pelajar yang berada di IPT tidak melalui pengalaman bergaul dengan rakan berbilang bangsa terutamanya mereka yang mendapat pendidikan awal di Sekolah Rendah Jenis Kebangsaan (SRJK).

\subsection{Objektif 2: Tahap Patriotisme di Kalangan Pelajar Tahun Satu}

Jadual 1.3 Taburan Kekerapan dan Peratusan Bagi Dimensi Patriotisme Di Kalangan Pelajar Tahun Satu

\begin{tabular}{|c|c|c|c|c|c|c|c|c|}
\hline \multicolumn{2}{|l|}{ Item } & SS & $\mathbf{S}$ & KS & TS & STS & Min & Tahap \\
\hline $\begin{array}{l}\text { Bangga menjadi warganegara } \\
\text { Malaysia }\end{array}$ & $f(\%)$ & $\begin{array}{c}382 \\
(73.3)\end{array}$ & $\begin{array}{l}114 \\
21.9\end{array}$ & $\begin{array}{c}20 \\
(3.8)\end{array}$ & $\begin{array}{c}5 \\
(1.0) \\
\end{array}$ & $0(0)$ & 3.68 & Tinggi \\
\hline $\begin{array}{l}\text { Sanggup mempertahankan } \\
\text { Malaysia dari serangan } \\
\text { musuh }\end{array}$ & $f(\%)$ & $\begin{array}{c}327 \\
(62.8)\end{array}$ & $\begin{array}{c}169 \\
(32.4)\end{array}$ & $\begin{array}{c}19 \\
(3.6)\end{array}$ & $\begin{array}{c}6 \\
(1.2)\end{array}$ & $0(0)$ & 3.57 & Tinggi \\
\hline $\begin{array}{l}\text { Sanggup berkorban untuk } \\
\text { Malaysia }\end{array}$ & $f(\%)$ & $\begin{array}{l}276 \\
(53)\end{array}$ & $\begin{array}{c}205 \\
(39.3)\end{array}$ & $\begin{array}{c}35 \\
(6.7) \\
\end{array}$ & $\begin{array}{c}5 \\
(1.0)\end{array}$ & $0(0)$ & 3.44 & Tinggi \\
\hline $\begin{array}{l}\text { Bersedia berbakti kepada } \\
\text { negara }\end{array}$ & $f(\%)$ & $\begin{array}{c}311 \\
(59.7) \\
\end{array}$ & $\begin{array}{c}188 \\
(36.1)\end{array}$ & $\begin{array}{c}20 \\
(3.8)\end{array}$ & $\begin{array}{c}2 \\
(40)\end{array}$ & $0(0)$ & 3.55 & Tinggi \\
\hline $\begin{array}{l}\text { Saya tidak sanggup menukar } \\
\text { warganegara sekalipun ada } \\
\text { peluang yang lebih baik di } \\
\text { negara luar }\end{array}$ & $f(\%)$ & $\begin{array}{c}282 \\
(54.1)\end{array}$ & $\begin{array}{c}135 \\
(25.9)\end{array}$ & $\begin{array}{l}78 \\
(15)\end{array}$ & $\begin{array}{c}26 \\
(5.0)\end{array}$ & $0(0)$ & 3.29 & Tinggi \\
\hline $\begin{array}{l}\text { Tidak rela nama Malaysia } \\
\text { diburukkan }\end{array}$ & $f(\%)$ & $\begin{array}{c}398 \\
(76.4)\end{array}$ & $\begin{array}{c}103 \\
(19.8)\end{array}$ & $\begin{array}{c}12 \\
(2.3)\end{array}$ & $\begin{array}{c}8 \\
(1.5)\end{array}$ & $0(0)$ & 3.71 & Tinggi \\
\hline \multicolumn{2}{|l|}{ Min keseluruhan } & \multicolumn{6}{|c|}{3.54} & Tinggi \\
\hline
\end{tabular}

Nota: $\mathrm{SS}=$ Sangat Setuju, $\mathrm{S}=$ Setuju,KS= Kurang Setuju, TS= Tidak Setuju, STS= Sangat Tidak Setuju, $f=$ Kekerapan, $\%=$ Peratusan

Hasil dapatan kajian dalam Jadual 1.3 menunjukkan secara keseluruhan pelajarpelajar tahun satu mempunyai tahap patriotisme yang tinggi $(\mathbf{M}=3.54)$. lni menunjukkan bahawa pelajar mempunyai rasa sayang dan cintakan negara, bangga menjadi warganegara Malaysia, setia dan sentiasa bersedia berbakti serta sanggup berkorban untuk negara. Hasil dapatan berkemungkinan disebabkan oleh usaha Kementerian Pendidikan melalui kurikulum dan ko-kurikulum sekolah yang telah menyemai nilai-nilai cintakan negara melalui program-program yang mampu membangkitkan semangat cintakan Negara menurut Surat Pekeliling Iktisas (Kementerian Pendidikan Malaysia, 1991) telah mengarahkan supaya semangat patriotisme di tanam dalam diri para pelajar sekolah melalui 
upacara-upacara seperti aktiviti menaikkan bendera Malaysia, menyanyikan lagu kebangsaan "Negaraku" dan melafaz ikrar taat setia yang dilakukan dalam perhimpunan mingguan atau harian.

Bagi sekolah yang mempunyai sistem siar raya yang baik, kemudahan ini dapat membantu kelancaran pelaksanaan mengenai semangat tersebut. Bagi upacara melafazkan ikrar taat setia upacara dijalankan secara kehormat, pengertian dan penghayatan oleh setiap pendidik dan pelajar. Contoh lafaz ikrar pelajar/cikgu adalah seperti berikut (Kementerian Pendidikan Malaysia, 1991):

"Saya (sebutkan nama) sebagai rakyat Malaysia dengan penuh kesedaran dan kesyukuran, membuat ikrar akan sentiasa memberi serta menumpukan taat setia yang tidak berbelah bagi kepada negara Malaysia yang saya cintai, saya berikrar akan sentiasa menjunjung prinsip-prinsip rukun negara pada setiap masa”.

Daripada ikrar pelajar-pelajar menunjukkan pihak kerajaan iaitu Kementerian Pendidikan secara serius berusaha menanamkan rasa taat setia dan sayangkan negara sejak daripada awal persekolahan. Oleh itu tidak hairanlah hasil kajian yang diperolehi menunjukkan tahap patriotisme pelajar IPTA adalah tinggi.

\subsection{GADANGAN}

Berdasarkan daripada dapatan kajian ini, pengkaji telah menggariskan beberapa cadangan untuk diberi perhatian oleh pihak-pihak tertentu.

(i) Di peringat sekolah rendah, menengah dan IPT di Malaysia perlu rnenerapkan elemen interaksi berbilang etnik dalam aktiviti kurikulum mahupun ko-kurikulum.

(ii) Hubungan sosial masyarakat boleh dipertingkatkan melalui inovasi kepada aliran pergaulan dalam kawasan kediaman. Inovasi ini merupakan usaha untuk mewujudkan semangat kejiranan melalui interaksi dalam organisasi yang formal seperti Rukun Tetangga, KEMAS dan persatuan penduduk. Tidak dapat dinafikan elemen pembangunan faktor fizikal seperti kedai, gerai, pasar, klinik, surau dan dewan merupakan elemen yang boleh memulakan bicara tentang hal-hal semasa sekalipun mereka belum pernah bertegur sapa.

(iii) Kempen-kempen kesedaran tentang integrasi nasional oleh kerajaan dan Badan Bukan Kerajaan (NGO) perlu dipergiatkan untuk meningkatkan hubungan sosial di antara kaum supaya hidup dalam harmoni dan bersatu padu. 
(iv) Di IPTA, kerajaan telah mewajibkan KHE bagi meningkatkan perpaduan dan intergrasi nasional. Oleh yang demikian pihak yang telibat perlu memastikan para pelajar mendapat input yang bersesuaian.

(v) Kempen untuk menyemai semangat Rukun Negara di kalangan setiap pelusuk masyarakat boleh membina semangat patriotisme di kalangan masyarakat berbilang etnik dan budaya sayang, cinta, kasih serta bangga menjadi warganegara Malaysia.

(vi) Penerapan komponen nilai-nilai murni perlu diserapkan ke dalam setiap mata pelajaran di sekolah atau IPT bagi menanamkan nilai norma seperti baik hati, keberanian, kebersihan fizikal, mental dan sebagainya. Nilai ini bukan sahaja diterapkan dalam interaksi sesama masyarakat malahan ia boleh diaplikasikan terhadap negara.

\subsection{KESIMPULAN}

Membentuk masyarakat yang berintegrasi dalam ikatan yang unggul merupakan satu cabaran kepada negara. Cabaran ini perlu disahut dan direalisasikan oleh semua peringkat masyarakat dari sejak dilahirkan sehinggalah ke liang lahat. Perpaduan etnik adalah prasyarat utama untuk mencapai hubungan sosial yang utuh serta untuk meningkatkan semangat patriotisme. Dapatan kajian ini diharap dapat membantu pihak-pihak tertentu dalam merangka program yang membabitkan aktiviti bersama antara etnik untuk memupuk keharmonian antara etnik dan semangat patriotisme bagi membentuk satu masyarakat yang kukuh dari segi kecintaan terhadap negara dan bersatu padu.

\section{RUJUKAN}

Blau, P. M. 1964. Exchange and Power in Social Life. New York: John Wiley \& Sons.

Hamidah Ab. Rahman, Paimah Atoma, Rozeyta Gmar, Mohd Sharil Bakri dan Fadilah Zaini. 2001. Kajian Keberkesanan Mata Pelajaran Umum Universiti Dari Aspek Jati Diri dan Kepekaan Globalisasi. Universiti Teknologi Malaysia: Skudai.

Holmes, G. J., Rempel, K. J. dan Zanna, P. M. 1985. Trusting close Relationship. Journal of Personality and Social Psychology. 49(1): 95-112.

Institut Tadbiran Awam Negara Malaysia. 1997. Dasar dasar Pembangunan Malaysia. Kuala Lumpur: INTAN.

Kementerian Pendidikan Malaysia. 1991. Surat Pekeliling Ikhtisas Bilangan 6/1991, Sukatan Pelajaran dan Peruntukan Masa Untuk Mata-Mata Pelajaran Program Kurikulum Bersepadu Sekolah Menengah (KBSM) Bagi Sekolah Menengah Rendah dan Sekolah Menengah Atas.

Kertas Kerja Kurikulum Kursus Tamadun Islam, Tamadun Asia (TITAS) dan Kursus Hubungan Etnik (KHE) di Institusi Pengajian Tinggi Awam, Fakulti Pengurusan dan Pembangunan Sumber Manusia (Untuk Penilaian Senat Universiti Teknologi Malaysia Skudai, Johor Darul Takzim). Jun 2005.

Nazaruddin Hj. Mohd Jail, Ma'rof Redzuan, Asnarulkhadi Abu Samah dan Ismail Haji Mohd Rashid. 2001. Pengajian Malaysia: Kenegaraan dan Kewarganegaraan. Kuala Lumpur: Pearson Education. 
Noor Sharifah Sutan Saidi. 1990. Pengenalan Perancangan Sosial di Dunia Ketiga. Kuala Lumpur: Dewan Bahasa dan Pustaka.

Rosman Mohd Yusoff, Hishamuddin Mat Som, Mohd. Janib Johari dan Shaari Majid. 2000. Kajian Keberkesanan Mata Pelajaran Universiti: Perspektif Klien (Majikan) dari Bekas Pelajar. Universiti Teknologi Malaysia: Skudai.

T'sui, S. A. dan O'reilly, A. C. 1989. Beyond Simple Demographic Effects of Relational Demography in superior-Subordinate Dyads. Academy of Management Journal. 32(2): 402-423. 